\title{
Business Network Positioning Analysis of Toyota
}

\author{
Zhen Li \\ School of Management, Jinan University, Guangzhou, China \\ Email: zhen_liiiii@sina.com
}

How to cite this paper: Li, Z. (2018) Business Network Positioning Analysis of Toyota. American Journal of Industrial and Business Management, 8, 1693-1699. https://doi.org/10.4236/ajibm.2018.87113

Received: June 21, 2018

Accepted: July 10, 2018

Published: July 13, 2018

Copyright (C) 2018 by author and Scientific Research Publishing Inc. This work is licensed under the Creative Commons Attribution International License (CC BY 4.0).

http://creativecommons.org/licenses/by/4.0/

\begin{abstract}
Business network positioning is of great importance to a firm. An enterprise should improve its power by managing the relationship with its upstream suppliers and downstream customers within its business network. Toyota is one of the successful automakers in the early $21^{\text {st }}$ century because of its unique positioning and supply chain management. This essay uses five forces analysis to study the power of Toyota in the business network and also looks at the problems that Toyota's position itself has encountered in its implementation during the crisis of the firm. By studying the experiences of its success and lessons of its downturn, other firms can improve its management and avoid bearing the similar difficulty.
\end{abstract}

\section{Keywords}

Business Network, Positioning, Supply Chain, Toyota, Strategy

\section{Introduction}

Business network positioning refers to building a unique strategy for the firm, which has a realistic and lasting guidance to the firm. It is related to the different operation activities of firms and the essence is selecting a positioning-centered operation activity system, thus constituting a strategic complementarity or division of labor in the industry or the whole economic system. In this definition, the unique positioning requires the business units with such position to have a comparative advantage and form the core of the firm strategy. Only such positioning can focus on corporate resources, thereby ensuring that the core value of business network positioning. Positioning is not vague but has the guidance and practical significance of long-term business operations. This is the only way to organically unify the long-term interests and the actual interests of firms to the strategy of firms. In this essay, Toyota is as an example to explore the important 
role of business positioning in firms being sustainably profitable.

Toyota Motor Corporation, an automotive industry manufacturing company operated in Toyota City, Aichi Prefecture, and Bunkyo-ku, Tokyo, is part of the Mitsui industrial zaibatsu. Founded in 1974 and developed into a predominantly automobile manufacturing firm, Toyota is Japan's biggest car company. It is a sizable industrial group operating in the fields of machinery, electronics and finance. Toyota's success is not only in the TPS (Toyota Production System), but also in its healthy partnership with suppliers, competitors and customers.

\section{Business Network and Positioning}

The match between business network and business network positioning is crucial. It transforms firm's position into firm's value, which is the most essential step of firm's strategy management. This is also a high-level model of business network positioning which is mainly to solve the problem of the development of various subsystems in the business network and try to promote the development of a business network through their own efforts. As a chain on a business network, a single firm needs different support and also supports the development of all the firms in the business network. It not only cultivates supporters but also even fosters competitors [1]. Proponents and competitors in a market economy are not absolute concepts, and "co-opetition" is the best choice for the firm. It is like a variety of creatures in the biological chain. Any changes in attempting to break the balance of the biological chain will shake the stability of the entire system. Similarly, the transitional competition of firms can worsen the support from the business network. Therefore, firms are required to try to make themselves as having a strong influence on the business network in the course of this game. The realization of such positioning goes through a long process of accumulation, which is mainly manifested in the accumulation of overall quality of the firm. If the firm lacks good quality, any position for the firm is meaningless.

\section{Five Forces Analysis of Toyota}

Porter's Five Forces Framework is a tool for analyzing competition of a business. It was developed in 1979 by Michael E Porter of Harvard Business School as a simple framework for assessing and evaluating the competitive strength and position of a business [2]. The model is useful because when directors understand the forces in the business environment or industry that can affect the profitability they will be able to adjust the strategy accordingly.

\subsection{Threat of New Entrants}

New industry entrants are sometimes an important force in the industry's competition. They are potential competitors that threaten Toyota's business. Most of the new entrants have new productive capacities and some necessary resources and expect to establish a favorable market position. In 2008, Japan's Toyota Motor Corporation has become the largest car manufacturer in the world and 
plays a decisive role in the automobile industry. The threat of new entry for Toyota is weak. The high expenses of establishing, maintaining and growing a new firm in the industry are significant entry barriers.

Facing the current situation, there are both advantages and disadvantages for Toyota. For the advantages, Toyota has achieved economies of scale in the car market, which can effectively increase investment to expand market share in order to resist the new entrants [3]. The disadvantage is there are still some vacancies in the automotive industry, such as electric car and intelligent car, which creates opportunities for some entrants into the industry. If Toyota wants to continue its leading position, it should actively take a differentiated advantage in the automotive industry.

\subsection{Threat of Rivalry}

The competition in the entire automobile market is fierce although the number of the major competitor in automotive market is small. In the global market, Toyota's major competitors are General Motors, Volkswagen, Daimler, BMW Group, Honda Motor, Ford Motor Company, Nissan, Hyundai Motor, SAIC Motor and others. The major trends are the strategic direction of product development, globalization and horizontal integration [4]. Toyota competes against other companies through cost management, fuel efficiency, marketing and other aspects. Major automobile manufacturers are racing to develop new models and new technologies in their vehicles to strive for new markets and penetrate current markets. The company must have comprehensive strategies to address the strong force of competitive rivalry.

\subsection{Threat of Substitutes}

Threats of substitutes come from three areas: the similar cars of other brands, public transportation and green car. Facing the increasing costs of purchasing, insurance, parking, maintaining and the promotion of green life, many people choose to use public transportation. However, different transportations have different functions to cater the needs of people so the threat from public transportation is not strong. With the continuous development of modern science and technology, a variety of new energy vehicles are increasingly being invented. The biggest challenge for automotive industry currently is to develop environment-friendly vehicles with suitable price and attractive styles [5]. At present, many automobile companies are actively developing new concepts of environmental protection and energy saving cars. Nations have promulgated corresponding policies to prompt the automobile manufacturing industry to implement the strategy of new energy vehicles. To moderate this threat, Toyota has released models that are low on fuel consumption, friendly to the environment and the smaller family cars are also less costly.

\subsection{Bargaining Power of Suppliers}

The factors favoring manufacturers are the smaller numbers of automakers 
compared to auto parts makers, and the scale of automakers is larger than the auto parts makers. Therefore, the automakers are supplier's major customers with stronger backward integration capabilities, stronger brand effect and higher purchasing power [6]. In such a situation, the supplier's bargaining power is weak. For Toyota, it proposed a "massive cost-savings campaign" in terms of design, manufacturing, procurement, and fixed costs, which has convinced suppliers that Toyota can help them achieve this goal with Toyota's force.

\subsection{Bargaining Power of Buyers}

The auto industry was also involved in the financial tsunami in 2008. Even now, the global automotive industry still temporarily fall into a doldrums, resulting in fiercer market competition. In order to attract customers, manufacturers were competing to cut prices and offered various discounts. The international market is a major market for all car brands. The brands that are available for consumption are rich in quality [7]. Customers can, to a considerable degree, bargain for prices, guarantees and other services, and their bargaining ability is also getting stronger. Faced with a diversified consumer market, the competition for brands, prices, services and new products is becoming more powerful. Such a market situation will result in Toyota's profitability decline.

\section{Supply Chain Management of Toyota}

The buying organization needs to develop an arrangement for supplier performance management to ensure that the agreed level of value for money is delivered. The buyer might also, on occasion, engage in supplier relationship management (SRM) to drive additional value-adding innovation.

\subsection{Cooperation with Suppliers}

In the supply chain management, Toyota separates the work of self-made parts to the cooperative plant which is regarded as a quasi-independent cooperative unit. Toyota maintains the same level of relationship with these cooperative facilities, namely that they are these cooperative facilities for other companies. Toyota has set up a strict system to assess the performance of its suppliers. There is a control center of the parts so that Toyota can get access to the real-time status of production. To improve the quality of the parts produced by suppliers, Toyota will share its information to suppliers during the period of developing a new product so that suppliers can well understand its design intention. Both of the above-mentioned methods are based on the mutual trust between Toyota and its suppliers. Apart from the correct tools and processes in production, Toyota also imparts the mindset of tackling problems and improving operations management with the hope that its suppliers can make progresses in their cooperation.

The alignments with suppliers have brought Toyota some benefits. The standardization of parts and the modularity of production contribute to the eco- 
nomics scale of production and the economics scale can decrease the cost of production. What is more, the well-operated supply chain offers Toyota advantage in time. The close cooperation can strengthen the ability to react the changeable market where timing is a significant factor.

Toyota integrates these selected suppliers into a "corporate network" to enable the consistent alignment of the interests and objectives of all its internal stakeholders. It can be said that Toyota not only regards suppliers as a general supply relationship, but integrates them into its own production system.

\subsection{Achievements in Dealing Relationships with Suppliers}

In terms of Toyota's supplier strategy, in a survey of the 2003 OEM Benchmark, one of the key indicators for assessing the relationship between manufacturers and suppliers in the US automotive industry, Toyota Motor Corporation have been rated as the most popular company to parts suppliers either in terms of trust, potential opportunities, or changes in research and development and other aspects. More than $70 \%$ of the parts suppliers voiced their willingness to cooperate with Toyota. This full trust between Toyota and its suppliers eliminates the quality inspections and significantly reduces transaction costs, enabling suppliers to proactively deliver technologies developed and provide expert advice on basic technologies [8]. It ensures enduring the competitive advantage of the technology and enables Toyota's supply chain to react quickly. With lower costs and shorter production cycles, as well as full use of supplier resources, Toyota enhances its core competencies.

\subsection{Managing Relationships with Customers}

Meeting the needs of customers is the key to the survival and development of firms in the market economy. As agencies are the direct organization which customers keep in touch with, Toyota attaches great importance in cultivating the CS (customer satisfaction) awareness in its sales outlets. Toyota also organized a research team of CS survey and commissioned the team to conduct customer satisfaction survey. The survey keeps in progress continuously and if the outcomes are beyond Toyota's expectation, that distribution branch will be cancelled.

Toyota applies $3 \mathrm{~T}$ principle in customer relationship management, that is: Total Employee Do, Total Customer Experience and Total Customer Satisfaction. It requires all the staff to devote themselves to make customers satisfied in all aspects during all process. The operational activities in a dealer are divided into three parts according to the principle: selling, service and maintaining. The mission of selling department is to let customers feel the joy of purchasing a car and deliver them to service department. The mission of service department is to let customers feel the joy of possessing a car and send them back to the gallery. The mission of maintaining department is to listen to the customers and create loyal customers. This is a circuit of Total Customer Satisfaction. 


\section{Ups and Downs}

\subsection{Successful Sales Network}

In order to survive under the challenge of strong US-European strength, Toyota increases overseas sales by setting up a market service department to train and motivate agents at all levels. Toyota's unique sales network makes it one of the largest-selling companies in the United States and the world. Toyota not only has the world's largest and perfect sales network but also creates its integration of business, service and spare parts supply. With a huge sales network, products and customers contact with high-quality service. After establishing a huge sales network around the world, Toyota has implemented a "rooted in the country" strategy in order to make it truly acceptable to consumers around the world. The basic philosophy of Toyota's strategy of "rooted in the country" is to abide the culture and customs of all countries and regions [9]. At the same time, it contributes to the local economy and social development through the business activities conducted in the local community. Thus, it enables Toyota to gain tremendous profits.

\subsection{Undulate Development}

However, Toyota's sustainable development is not easy. In a recall event, there were frequent quality problems in Toyota's gas pedals and brake system components. This situation is unacceptable to Toyota because the company always insists on quality and safety. We also have to reflect on Toyota's supplier strategy. Under the strategy of long-term cooperation and benefit sharing between Toyota and its suppliers, there seems to be a contradiction that if the long-term cooperation with a few suppliers is realized and even the actual control and benefit sharing for some main component suppliers are realized, in order to ensure the quality of spare parts, Toyota can only supervise and control the quality more, instead of adopting market-oriented competition mechanisms like GM and Ford to choose the best suppliers with the lowest prices and the highest quality [10]. In addition, while pursuing rapid revenue growth, Toyota uses cost reduction strategy has replaced the strategy of "origin of manufacturing" that has always been dominant. As a result, Toyota's production mode has been eroded and gradually abandoned. The excess capacity led to increased cost pressures, in which case, cost pressures may be sacrificed by low quality. Therefore, in 2008, Toyota suffered a loss of 4.4 billion US dollars due to the international financial crisis and its rapid expansion. There is nothing wrong with expanding its business to meet the needs of consumers around the world, but Toyota's expansion is beyond reasonable limits.

\section{Conclusion}

Toyota's unique positioning in the international development process and supply chain management make it become successful in the fierce competition. However, at a time of the crisis of Toyota' recalls, as well as in the context of an 
increasingly complicated quality issue and an increasingly complex international environment, we are also forced to look at the problems that Toyota's position itself has encountered in its implementation. While continuing to learn the successful experiences of others, firms should also explore what kind of position suits their own situation, circumstances and the international environment. Only in this way can firms truly recognize the internal weaknesses and strengths, as well as external opportunities and threats, eventually achieving sustainable development.

\section{Acknowledgements}

I would like to express my gratitude to those who have helped me during the writing of this essay. I gratefully appreciate the help of Frank Rowbotham, the lecturer of business strategy and supply chain management, for his encouragement and guidance. I would also like to say thank you to my personal tutor Jimmy, it is the personal meeting with you that inspired me to think about this industry. Lastly, my gratitude also extends to my family who has been assisting, supporting and caring for me during my study.

\section{References}

[1] Winch, G. (2014) Strategic Business and Network Positioning for Internationalisation. Service Industries Journal, 34, 715-728. https://doi.org/10.1080/02642069.2014.886196

[2] Ford, D., Gadde, L.E., Håkansson, H., et al. (1998) Managing Business Relationships. Journal of Wiley, 80-81.

[3] Warsta, J. and Seppänen, V. (2007) Value Network Positioning of Expected Winners: Analysis of the Top Software Business Start-Ups. Springer US, 67-68.

[4] Murto, P. and Person, O. (2015) Environmentally Sustainable Design in a Business Network: A Study on the Position of Designers in the Development of a Passenger Ship. Design Management Journal, 10, 37-49. https://doi.org/10.1111/dmj.12021

[5] Choi, S.J. and Lu, J. (2013) Returnee Faculty Members, Network Position and Diversification Strategy: An Analysis of Business Schools in China. Asia Pacific Business Review, 19, 559-577. https://doi.org/10.1080/13602381.2012.739361

[6] Moran, M.R., Façanha, S., Gonçalves, M.A. and Fischmann, A.A. (2012) Congruencies between Strategic Positioning and Business Networks: Case Study of a Multinational Subsidiary in Brazil. Rev. Adm, 47, 68-80.

[7] Grzeskowiak, S., Blut, M. and Kenning, P. (2007) Market Orientation in Vertical Business Networks. Journal of Marketing Channels, 14, 31-50.

https://doi.org/10.1300/J049v14n03_03

[8] Tsai, W. (2001) Knowledge Transfer in Intraorganizational Networks: Effects of Network Position and Absorptive Capacity on Business Unit Innovation and Performance. Academy of Management Journal, 44, 996-1004.

[9] Yu, C., Wang, W., Chang, C.W. and Heng, M.S.H. (2004) The Levels of Information Technology Adoption, Business Network, and a Strategic Position Model for Evaluating Supply Chain Integration. Journal of Virological Methods, 119, 57-64.

[10] Ritala, P. and Huizingh, E. (2014) Business and Network Models for Innovation: Strategic Logic and the Role of Network Position. International Journal of Technology Management, 66, 109. https://doi.org/10.1504/IJTM.2014.064608 